Open Access

\title{
Knowledge-based, smart and sustainable cities: a provocation for a conceptual framework
}

\author{
Daniel Lage Chang ${ }^{1}$, Jamile Sabatini-Marques ${ }^{1}$, Eduardo Moreira da Costa ${ }^{1}$, Paulo Mauricio Selig ${ }^{1}$ \\ and Tan Yigitcanlar ${ }^{2^{*}}$ (i)
}

* Correspondence: tan@ worldcapitalinstitute.org

${ }^{2}$ World Capital Institute, 60 Ridge Street, Greenslopes, QLD 4120, Australia

Full list of author information is available at the end of the article

\begin{abstract}
The smart and sustainable cities concept has become a globally hot topic during the last few decades, particularly following the catastrophic impacts of global climate change. The assessment of smart and sustainable cities, however, is a major challenge due to complex, complicated, and chaotic nature of our cities. This makes the available monitoring and evaluation tools difficult to adopt and apply in different urban contexts to support urban planning and governance and foster evidence-based policymaking. In order to address this issue, the paper brings together knowledge-based development concept with smart and sustainable cities. Knowledge-based development is a vision of development that considers knowledge as the central structuring element of a development strategy. Similarly, its more territory focused version, knowledge-based urban development is an integrated approach for the transition of cities and regions into sustainable, liveable and prosperous localities. The methodological approach of the paper includes the review of the literature on existing approaches on smart and sustainable cities assessment, describing their main aspects, strengths and limitations, and discuss the potential contribution of a knowledge-based urban development strategy for the successful promotion of smart and sustainable cities, presented in a proposed conceptual framework.
\end{abstract}

Keywords: Sustainable cities, Smart cities, Sustainability assessment, Knowledge-based development, Knowledge-based urban development, Urban living labs

\section{Introduction}

The UN's 2030 Agenda for Sustainable Development presents a new scenario, where sustainability is at the mainstream of the global development strategy. The identification of objectives and metrics applied in the urban context are on the spotlight, mostly driven to measure the decarbonisation of productive activities and the management of commons, such as waste management, energy, water, transportation and urban mobility, urban infrastructure, to name a few of them. As stated by Phillis et al. (2017, p.254), unprecedented impacts in the biosphere are expected as the result of operating out of regular boundaries: "climate change, loss of biodiversity and the nitrogen cycle. In a sense, humanity has embarked on an experiment of global scale in these three areas with unknown consequences that threaten the very foundations of sustainability".

(c) The Author(s). 2018 Open Access This article is distributed under the terms of the Creative Commons Attribution 4.0 International License (http://creativecommons.org/licenses/by/4.0/), which permits unrestricted use, distribution, and reproduction in any medium provided you give appropriate credit to the original author(s) and the source, provide a link to the Creative Commons license, and indicate if changes were made. 
A sustainable city is a vision of the future, shared by its citizens. In order to provide better quality of life in the present while maintaining or expanding the possibilities of well-being and prosperity for future generations. Mori and Yamashita (2015) view a sustainable city as the one that can generate the maximum socioeconomic benefits for its population without losing the environmental and equity parameters, measured by appropriate indicators. Concepts linked to environmental protection to characterise cities have given rise to initiatives and experiments such as green city, eco-city, lowcarbon city, smart city, evolving towards more integrated approaches to sustainability (Yigitcanlar and Kamruzzaman 2015; Trindade et al. 2017). Among such variety of concepts, sustainable city has both a greater occurrence and centrality with other category of cities in the scientific literature (De Jong et al. 2015). During the last decade, a new form of city has been rapidly gaining high popularity - that is smart cities (Lara et al. 2016; Yigitcanlar 2015, 2016). A smart city, for instance, will seek the goal of achieving its sustainability with the support of modern technologies; in fact, information and communication technologies (ICTs) can bring numerous benefits to cities, but its implementation as an end in itself is not enough to make it a sustainable city (Ahvenniemi et al. 2017). For this reason, this paper refers to the ideal form of the 21st Century cities as 'smart and sustainable cities' (Yigitcanlar and Lee 2014; Yigitcanlar and Kamruzzaman, 2018).

The lack of conceptual consensus and the intrinsic difficulty of defining something holistic and fluid as a smart and sustainable city appears in the scientific literature, unable yet to establish a comprehensive approach that deals in the urban scale with the many dimensions of sustainability (Maiello et al. 2011). How, then, can we to tackle the problem? In addition to the need of overcoming unidimensional measures for a holistic approach that organises the city's urban development (Egger 2006; Ding et al. 2015), a city must have its environmental restrictions applied in an intergenerational context in order to be sustainable (Mori and Yamashita 2015). These characteristics make the assessment of smart and sustainable cities a permanent and never static challenge (Yigitcanlar 2009).

Knowledge-based development (KBD) is a vision of development that considers knowledge as the central structuring element of a development strategy for cities and regions (Yigitcanlar 2010; Lönnqvist et al. 2014). For instance, the capital systems approach is a KBD methodology for measuring value that takes into consideration many dimensions and aspects of life that goes far beyond traditional assessment views (Carrillo et al. 2014). Carrillo (2014, p.416) defines KBD as "the collective identification and enhancement of the value set whose dynamic balance furthers the viability and transcendence of a given community". Knight (1995) envisioned KBD of cities as basis for sustainable development, emphasising the relevance of the process of transforming knowledge resources into local development. Following this view, cities should build their own unique knowledge stock by identifying their own particular strengths. After two decades, Knight's statement on knowledge-based urban development (KBUD) seems very adequate to describe actual challenges: "The increasing importance and complexity of the city and the requirement that development is sustainable calls for a new integrative framework for thinking about the development of cities. Urban planners are facing new issues and need new approaches in order to facilitate new forms of development" (Knight 1995, p. 247).

Ergazakis and Metaxiotis (2011) stress the challenging nature to deliver a KBUD approach and point the standardisation of assessment methods and metrics as the key 
to foster KBUD implementation. Carrillo (2014, p. 406) notes that KBUD as a disruptive perspective transcends sustainability goals, still the "convergence between KBUD and sustainability is a positive and coherent one". Sarimin and Yigitcanlar (2012) sees KBUD as a critical approach for achieving sustainability-quadruple bottom line (economy, society, environment, governance)-in our cities. In other words, KBUD is an integrated approach for the transition of cities and their regions into places of attraction, retention and development of intellectual and human capital that will ultimately create a knowledge dynamics applied to the urban context and foster innovation to promote an integral and sustainable development of the territory-not only for the economic terms, but also environmental and societal terms (Pancholi et al. 2015; Yigitcanlar et al. 2012, 2017). Baum et al. (2009) see KBUD as a critical driver for providing regional outcomes though creative industries.

Against this brief background the following questions come to mind. What are the strengths and limitations of the existing approaches on the assessment of sustainable cities present in the scientific literature? How do they propose to handle the challenging task of monitoring and evaluation of a city in order to promote sustainability? What can a better framework be developed to address the sustainability issues of our cities?

This paper highlights an understanding on these issues, and discusses a theoretical KBUD strategy for the promotion of smart and sustainable cities, presenting a conceptual framework with three main components-i.e., implementation drivers, knowledge management integrated approach, and monitoring and evaluation-pointing towards a promising field of future urban research and practice.

\section{Methodology}

The method used for the literature review includes systematic search flow (SSF) approach developed by Ferenhof and Fernandes (2016). The systematic review is "a method of scientific investigation with a rigorous and explicit process to identify, select, collect data, analyse, and describe the relevant contributions to research" (Ferenhof and Fernandes 2016, p. 551). This method consists of three distinct phases: the definition of the research protocol, the analysis of the data and, finally, the synthesis. Selection of this method was due to its effective way to demonstrate the procedures applied at each stage of the systematic review production, in order to process, analyse, and produce the synthesis with consistency in the production of scientific knowledge.

The search strategy used involved the use of the terms "sustainable cities" OR "smart cities" AND "framework" OR "model" OR "assessment" AND "evaluation" OR "indicator". This strategy sought not to restrict results only to evaluation models, but given the diversity of existing approaches to the theme, it could also select from articles that associate sustainable indicators and cities.

In relation to the database query, the Scopus and Web of Science databases were selected, both searched on December 2017. The Scopus database found 80 results, of which 49 are published articles. The Web of Science database found 68 results; after the filtering of only published articles, there were 39 results. Starting from the 86 articles combined from the both Web of Science and Scopus databases, and removing 30 duplicate results, 56 results remained. The organisation of the bibliographies was carried out using the Mendeley software, and the results were aggregated by each consulted database. 
For the step of standardising the selection of articles, sequential filters were applied for reading summaries and reading articles. Articles that present an integrated vision, whether multidisciplinary or multidimensional in their proposed model or analysis, or in the metrics used, indicators or indexes, and which are directly associated to the theme sustainable cities, were selected. Articles dealing with sustainability only in a specific dimension or in a single disciplinary way were discarded. The final composition of the article portfolio resulted in 20 papers representative of the researched theme.

Following this stage of literature review, a conceptual framework development was done by determining the key trends in urban research that aims to deliver sustainable outcomes for our cities. The paper brought together several concepts, such as KBD, KBUD, and urban living labs, to constitute a new conceptual understanding, and operational capabilities to better address the sustainability issue of our cities.

\section{Smart and sustainable city assessment frameworks}

There is a reasonable variety of approaches on assessment models, frameworks, indexes and rankings, and monitoring and evaluation tools that deal with smart and sustainable cities or the urban smartness and sustainability assessment of cities in the scholarly literature. The need for multidimensional assessments is necessary when working with different typologies of cities, such as smart, sustainable or competitive (Monfaredzadeh and Berardi 2015). The comparison of assessment models of sustainable cities and smart cities in Ahvenniemi et al. (2017) reveal that urban sustainability assessment systems are more complete for the natural environment, built environment, water and waste management and energy categories, while smart cities frameworks best cover economic issues. Nonetheless, aspects related to environment and energy are undersized in smart cities frameworks: environmental indicators are lacking, even though the reduction of greenhouse gas (GHG) and energy consumption are central to the smart city agenda.

Measuring the smartness and sustainability of a city are "infinitely complex because city systems are interrelated and in constantly changing" (Choon et al. 2011, p.28). If reaching a sustainable system as a whole seems a quasi-utopian mission, an urban metabolism approach can be extremely effective in achieving a more sustainable energy consumption pattern by directly addressing energy consumption in dwellings and urban mobility. Urban metabolism focuses on the material and energy flows and waste generated by urban processes (Kennedy 2002; Prata et al. 2014; Goonetilleke et al. 2014; Yang et al. 2014).

Smart and sustainable cities assessment models gain key importance as local governments make commitments to reduce $\mathrm{CO} 2$ emissions and need adequate instruments to measure their performance (Bourdic et al. 2012; Kamruzzaman et al. 2015). According to Egilmez et al. (2015), CO2 emissions per capita and percentage of workers moving using public transportation and or non-motorised modes can significantly affect the sustainability performance of a city. For example, the city of Aveiro in Portugal, would achieve a higher energy efficiency and a reduction of $62 \%$ in $\mathrm{CO} 2$ emissions with the integration of the energy systems and urban mobility from renewable sources and the use electric vehicles (Prata et al. 2014, p.881).

The task, however, is much more complex than measuring a city's GHG emissions. Kennedy (2002) remarks that urban smartness and sustainability assessment is often a costly endeavour and ideally should include elements of interaction that goes beyond 
the city, such as air pollution. Tumini (2016) highlights that the integration of resilience into government policies and instruments focused on urban sustainability can reveal the potential to better harness the synergies between sustainability and resilience for the smart and sustainable development of cities.

The realities of cities in countries with different levels of development are quite different. According to Ding et al. (2015), multidimensional frameworks for smartness and sustainability assessment are often designed to cities in developed countries, and when applied in cities of developing countries they end up presenting major limitations, so for the assessment of those emerging cities it would make more sense to start from existing models or frameworks with simple and easy-to-understand implementation. Following this line, Tumini (2016) argues that rather than imposing ready-to-use models of urban development at a high cost would be to allow a region's own natural development, working its urban regeneration from its constituent elements and a holistic understanding of the territory.

Indicators are essential tools to support decision-making processes towards the smart and sustainable development of cities and should reflect the aspirations of their citizens in order to express the inputs of the multiple actors present in the urban environment (Choon et al. 2011). Subjectivity in the choice of indicators is somehow inevitable given the diffuse nature of the concept of sustainability and the lack of more straightforward definitions (Phillis et al. 2017). In addition, indicators for smart and sustainable cities are far from any consensus, given the asymmetry of views founded in existing models.

The systematic use of indicators for monitoring and evaluation of sustainable cities, regardless of the model or framework adopted, is necessary for quality, reliability and comparability of data over time. However, the assessment of a city is not always transparent in the choice and justification of the indicators. Bourdic et al. (2012, p.600) call attention to the fact that in some extent, indicators in urban smartness and sustainability assessment tools "mix different mathematical equations without revealing them or explaining in detail what exact information they give".

In fact, indicators should be instruments to measure what matters, insofar as they relate to specific topics of interest or specific areas of the city. Instead of making new lists of indicators of urban sustainability, Mori and Yamashita (2015) investigate how indicators can be able to assess the sustainability of a city and compare them with others, pointing that city assessments measure an instant picture of their sustainability, but they cannot tell whether a city is on a positive or negative trajectory.

The studies found in the literature reviewed are presented in Table 1, highlighting their strengths and limitations. The analysis has not picked up any specific smart city assessment tools or metrics in the literature. Existing literature seems to be more focused on the conceptual frameworks or specific technology aspects of these cities. The paper provides a brief description of the sustainability assessment studies that contain sustainable city assessment models below-where some of these also could be applied to smart city context.

Platform for sustainable urban models (CAT-MED)

CAT-MED is a model that starts from three concepts to define the development process of a city: complexity, compactness and proximity to basic services. Tumini 
Table 1 Sustainable city assessment models

\begin{tabular}{lll}
\hline Literature & Approach & Strengths and Limitations \\
\hline Ahvenniemi & Comparative analysis between smart & Strengths: The analysis reveals the lack of more \\
et al. (2017) & environmental indicators in smart cities assessment \\
& assessment frameworks & frameworks. The authors proposed the term 'smart \\
& & sustainable cities' to evolve existing frameworks in \\
& order to make them more complete. \\
& Limitations: The method stage of allocating points \\
& to parameterise indicators can generate bias \\
in results.
\end{tabular}

Arslan et al. Neighbourhood development. Leadership (2016) in energy and environmental design neighbourhood pattern and design (LEED-NPD)

Baffour and Booth (2014)

Neighbourhood concepts integrated framework

Bourdic et al. Urban morphology (2012)

Choon et al. Sustainable city index for Malaysia (2011)

Ding et al. (2015)

Multidimensional framework. Trinity of cities sustainability from the time, space and logic dimensions (TCS-SLTD)

Egger (2006)

Sustainable city model, integration between global and local

Egilmez et al. (2015)

Fuzzy multi-criteria decision-making approach (MCDM)

Kennedy (2011) Urban metabolism. Transportation systems
Strengths: The LEED-NPD tool has proven to have unique strengths to adapt to sustainable development goal (SDG) \#11.

Limitations: The tool has brought new elements to the study districts, but fails to respond to the current and future needs of citizens in relation to improving the quality of urban life.

Strengths: There is a harmony between the conceptual principles of neighbourhood and principles of sustainability, and this can be seen in the convergence of indicators used that point to a more productive and efficient city in terms of resources utilisation.

Limitations: Well-being is not only about wealth growth and its equity distribution, but also about a balanced natural environment and social integration.

Strengths: Urban morphology favours a systemic and integrative approach to urban challenges and is significant for socioeconomic and environmental issues.

Limitations: The choice of the indicators and the attribution of the weights is subjective and as we do not work with benchmarks values the results can vary a lot.

Strengths: Well suited to the Malaysian national context, allowing comparability between cities. Limitations: There is no further analysis on the proposed framework.

Strengths: The process proposed by the tool can adapt to different cities in developing countries. Limitations: The model points to important trends that have occurred over time in the city such as population growth and urban sprawl but does not detail other important aspects of sustainability assessment.

Strengths: Evaluates the impact of the city beyond its limits, allowing a more integral vision of sustainability and not just the simple transfer of externalities from one region to another. Limitations: Conditions indicators are a photograph of the city's moment and do not provide sufficient evidence about the sustainability of the city.

Strengths: The integrated methodology that links diffuse MCDM and expert panel can be useful when evaluating multiple positive and negative indicators in impact categories. Limitations: The beaconing by experts about the importance and relative weight of indicators can bring more efficiency to the model, but risks creating bias in the evaluation.

Strengths: The proposed methodology is made on urban metabolism and sustainability indicators to evaluate urban sustainability. Limitations: the study integrates environmental, 
Table 1 Sustainable city assessment models (Continued)

Literature Approach

Strengths and Limitations

economic and social dimensions of sustainability, but is limited to the transportation sector.

Liu et al. (2014) Cases analysis of concept cities in China

Strengths: The study analyses the objectives and indicators of cities with different concepts: Tangshan Bay (Eco-city), Baoding (Low-carbon city), Shenzhen (Low-carbon eco-city) Limitations: The proposed metabolic thinking and eco-model seems tailored for Tangshan Bay and difficult to replicate to other concept cities

Maiello et al. Case studies to unidisciplinary, (2011) multidisciplinary and transdisciplinary visions

Strengths: Highlights the need of transdisciplinary vision to promote sustainable cities. Presents the relation between knowledge and urban sustainability.

Limitations: Analysed cities are restricted to Tuscany region in Italy. Multidimensional analysis was built in unidimensional scenario.

Monfaredzadeh Comparative analysis between smart cities, and Berardi sustainable cities and competitive cities (2015)

Strengths: Demonstrate how each system of cities emphasise certain issues that reveals some contradictions that emerge when trying to tackle a different concept for which the given city assessment system was built. Limitations: There is no specific recommendations on how each of these systems can be improved.

Mori and Assessment framework of the city Yamashita sustainability index (CSI)

Phillis et al. Combination of statistical smoothing (2017) with fuzzy logic sustainability assessment by fuzzy evaluation (SAFE)

Prata et al. Urban metabolism, and material flows (2014)

Tumini (2016) Sustainability and resilience integrated approach (CAT-MED)

Yang et al.

Urban metabolism energy synthesis approach

Strengths: The analysis uses five examples of city sustainability assessment in order to judge and compare the results.

Limitations: Constraint indicators should set clear limits for sustainability.

Strengths: It points to the three indicators with the greatest potential for improvement. Allows comparability.

Limitations: Subjectivity in the choice of indicators.

Strengths: Adapts the city metabolism model of Newman (1999) with Sherry's (2002) materials and energy flow to assess green urban mobility and energy efficiency.

Limitations: The demonstration of impact on $\mathrm{CO} 2$ emissions reduction is clear, but not enough to capture other sustainability aspects that a city has.

Strengths: The results show the potential to take advantage of the synergies between the visions of sustainability and resilience for a better development of cities.

Limitations: The model needs new applications to check its consistency.

Strengths: Demonstrates integration between economic, social and ecological dimensions. Provide insights into cross-boundary metabolic interactions and system metabolic sustainability. Limitations: Besides its efforts the approach is still not enough to assess cities' sustainability in a holistic way.

Strengths: It is an integrated model that factors in various aspects of sustainability in an urban context, which models infrastructure, land-use, environment and transport systems to determine their combined sustainability. Limitations: This geographical information system (GIS) based sustainability assessment model is data hungry model. Challenges in data collection makes the model's operability difficult 
Table 1 Sustainable city assessment models (Continued)

\begin{tabular}{|c|c|c|}
\hline Literature & Approach & Strengths and Limitations \\
\hline $\begin{array}{l}\text { Yigitcanlar et al. } \\
\text { (2015a) }\end{array}$ & $\begin{array}{l}\text { City multiscalar approach of the } \\
\text { city prosperity index }(\mathrm{CPI})\end{array}$ & $\begin{array}{l}\text { Strengths: For the CPI, the authors suggest a } \\
\text { multiscale approach that goes beyond macro } \\
\text { level assessment for micro and medium scales. } \\
\text { Limitations: Since the acquisition of MUSIX data } \\
\text { is slower and more complex it was not possible } \\
\text { to aggregate this index in the multiscale study. }\end{array}$ \\
\hline $\begin{array}{l}\text { Yigitcanlar et al. } \\
(2015 c)\end{array}$ & $\begin{array}{l}\text { Neighbourhood sustainability } \\
\text { assessment index (NSAl) }\end{array}$ & $\begin{array}{l}\text { Strengths: The NSAI tool works efficiently at the } \\
\text { local scale and allows decision-makers to } \\
\text { evaluate local neighbourhoods' sustainability } \\
\text { levels adequately. } \\
\text { Limitations: The index is data hungry model. } \\
\text { When it gets to larger scales, this makes the } \\
\text { index's operability difficult. }\end{array}$ \\
\hline
\end{tabular}

(2016) suggests a methodological framework for urban planning tools to adapt sustainability design to resilience requirements. The framework generates from the CAT-MED indicators distributed in the following categories: Territory and city; Mobility and transportation; Natural resource management; Social and economic cohesion.

\section{City prosperity index (CPI)}

CPI is an initiative of the UN agency HABITAT, which provides cities with tools to create indicators and information to support the process of sustainable urban development. The proposed multiscale approach in Yigitcanlar et al. (2015a) provides a more accurate view of the environmental sustainability assessment of urban areas, one of the central perspectives when dealing with urban sustainability. There are two systems of sustainability indicators: MUSIX (Urban Ecosystem Sustainability Index Micro Level) (Dizdaroglu and Yigitcanlar 2014, 2016), and ILTIM (Model of Transportation Indexing and Integrated Soil Use at Neighbourhood Level) (Dur et al. 2014; Dur and Yigitcanlar 2015). This approach has the potential to expand the social and economic dimensions of sustainability, as well as to add other modules and generate an urban sustainability index capable of comparing cities.

\section{City sustainability index (CSI)}

To assess sustainability in CSI by applying two categories of indicators-maximisation and restriction-is the proposal of Mori and Yamashita (2015). There are three basic requirements: strong sustainability, relative and absolute evaluation, and evaluation of the leakage effect, to arrive at a CSI conceptual framework.

\section{Multi-criteria decision-making approach (MCDM)}

MCDM involves the development of a conceptual framework, the attribution of weights by a panel of experts and the application of the model (Egilmez et al. 2015). The model is composed of 16 sustainability indicators grouped into seven impact areas, including air, energy, soil, water, buildings, transportation, and waste.

\section{Sustainability assessment by fuzzy evaluation (SAFE)}

Overall urban sustainability in the SAFE model (Phillis et al. 2017) is measured by two groups of indicators: (a) Environmental sustainability, consisting of three secondary components, including air quality, water quality, and soil quality and integrity to sea 
level rise; and (b) Social or human sustainability, consisting of four secondary components, including health, economic welfare, education and civic environment. There are 46 basic indicators, which generate indexes from the characteristics grouped by fuzzy inference.

\section{Sustainable city model (SCM)}

The city is seen as a holistic whole and not an isolated system in SCM proposed by Egger (2006), including the city's impacts generated outside its domains. The characteristics of a sustainable city must be measurable and provide insight into the complex interactions between environment, economy and society. The model seeks to integrate sustainability in all its elements and presents two perspectives - the network and the being-for interconnectivity between the global and the individual. Indicators are structured in three broad categories: global capital, city capacity, and conditions. According to Egger (2006), this integration establishes a balance of forces between the city's role in being in the global scenario of competitiveness and at the same time providing a good quality of life for its citizens.

\section{Trinity of cities sustainability from the time, space and logic dimensions (TCS-SLTD)}

The TCS-SLTD conceptual framework proposed by Ding et al. (2015) is a model for assessing sustainable development of cities in developing countries. The spatial pattern of urban areas refers to the spatial dimension, and its sustainability is measured by compactness. Sustainable development indicators are selected guided from DPSIR (drivers-pressures-states \& impacts-responses) framework (Dizdaroglu et al. 2012; Yigitcanlar and Dizdaroglu 2015). Finally, in its temporal dimension, eight thematic aspects of indicators are collected in time series, including population growth, economic development, requirements for social welfare improvement, business prosperity, industrial optimisation, future proofing, environmental impacts, and quality of life of residents.

\section{Urban morphology}

The urban morphology approach is an alternative vision to contribute to reducing energy consumption and greenhouse gas emissions (GHGs), where urban actors can benefit from this system and better understand the relationships between the built environment and energy consumption. The system proposed by Bourdic et al. (2012) is made of 60 spatial indicators of crossed scales, based on three pillars: urban form, economic and social, and environment. Indicators are set according to seven types, including intensity, diversity, proximity, complexity, form, connectivity, and distribution. The spatial scales are the city, the district, the neighbourhood, the block and the building.

Our findings of the literature review on smart and sustainable cities' assessment reveal the amplitude of approaches and a certain asymmetry in the way that each one of them deal with monitoring and evaluation tools, and how they propose to be implemented by cities. Most of the gaps for higher consistency in assessing smart and sustainable cities seems to be due the lack of an integrated approach to embrace in a comprehensive way the full spectrum of possibilities that can contribute to the overall objective of the sustainable development of cities.

At this very point, we believe that a KBUD approach could fill this gap by allowing an operational implementation to achieve smart and sustainable city development goals associated with a flexible structure of measuring value to monitor and evaluate the 
whole development process that a city pursues. In order to fuel the discussion on the topic and bring it to the reality of cities to advance the experimentation on new ways of promoting faster and consistent smart urban sustainability transitions, a conceptual framework is presented in the following section of the paper.

\section{Knowledge-based, smart and sustainable cities}

Knowledge-based, smart and sustainable city is a conceptual framework that displays a KBUD strategy aimed to promote smart and sustainable cities through the operationalisation of a knowledge management integrated approach, based on the KBUD framework designed by Yigitcanlar and Lönnqvist (2013). Before the description of the proposed conceptual framework, a common understanding of what the referred KBUD framework stands for is necessary (Fig. 1). KBUD stands for what Yigitcanlar (2011, p.354) has defined as "the new development paradigm of the knowledge era that aims to bring economic prosperity, environmental sustainability, a just socio-spatial order and good governance to cities". KBUD has set a new paradigm of urban planning.

The KBUD framework wires four development domains of knowledge, including economic, socio-cultural, enviro-urban, and institutional (Yigitcanlar 2011, 2014a). The economic development domain is structured over the knowledge economy foundations, where knowledge is the key production factor of added value to produce prosperity. The socio-cultural development domain is intended to produce equity by designing and implementing several educational and cultural strategies to enhance human and social capital and creating a broad space of opportunities for people to develop their skills. The enviro-urban development domain will produce sustainability where spatial quality is achieved by fostering sustainable urban development and a better quality of life and place. The institutional development domain produces enablers of a knowledge governance that creates a good governance climate and eventually generates organisational quality.

In terms of implementation, the model is applied to numerous contexts. For instance, Yigitcanlar et al. (2015b) demonstrated new possible understanding on cities' profiles and possible levels of comparison by successfully applying KBUD assessment framework in Finnish cities. Similarly, Yigitcanlar and Bulu (2015) applied the framework in Turkey. Additionally, Yigitcanlar and Sarimin (2015) adopted the framework to evaluate the Multimedia Super Corridor's KBUD in Malaysia.

This paper brings together the KBUD concept with smart and sustainable cities. By doing so, the paper proposes a knowledge-based, smart and sustainable city conceptual framework. The proposed knowledge-based, smart and sustainable city conceptual framework is made of three main components: (a) Implementation drivers; (b) Knowledge management integrated approach, and; (c) Monitoring and evaluation (Fig. 2).

\section{Implementation drivers}

Implementation drivers refers to the combination of three axis-governance, innovation, and sustainability-enliven in urban living labs, neutral spaces of knowledge co-creation that function as innovation hub of people from different sectors and backgrounds, leaders of urban experimentation in the city, interacting to design, prototype and deploy solutions to urban challenges. Urban living labs are defined by Voytenko et al. (2016) as places 


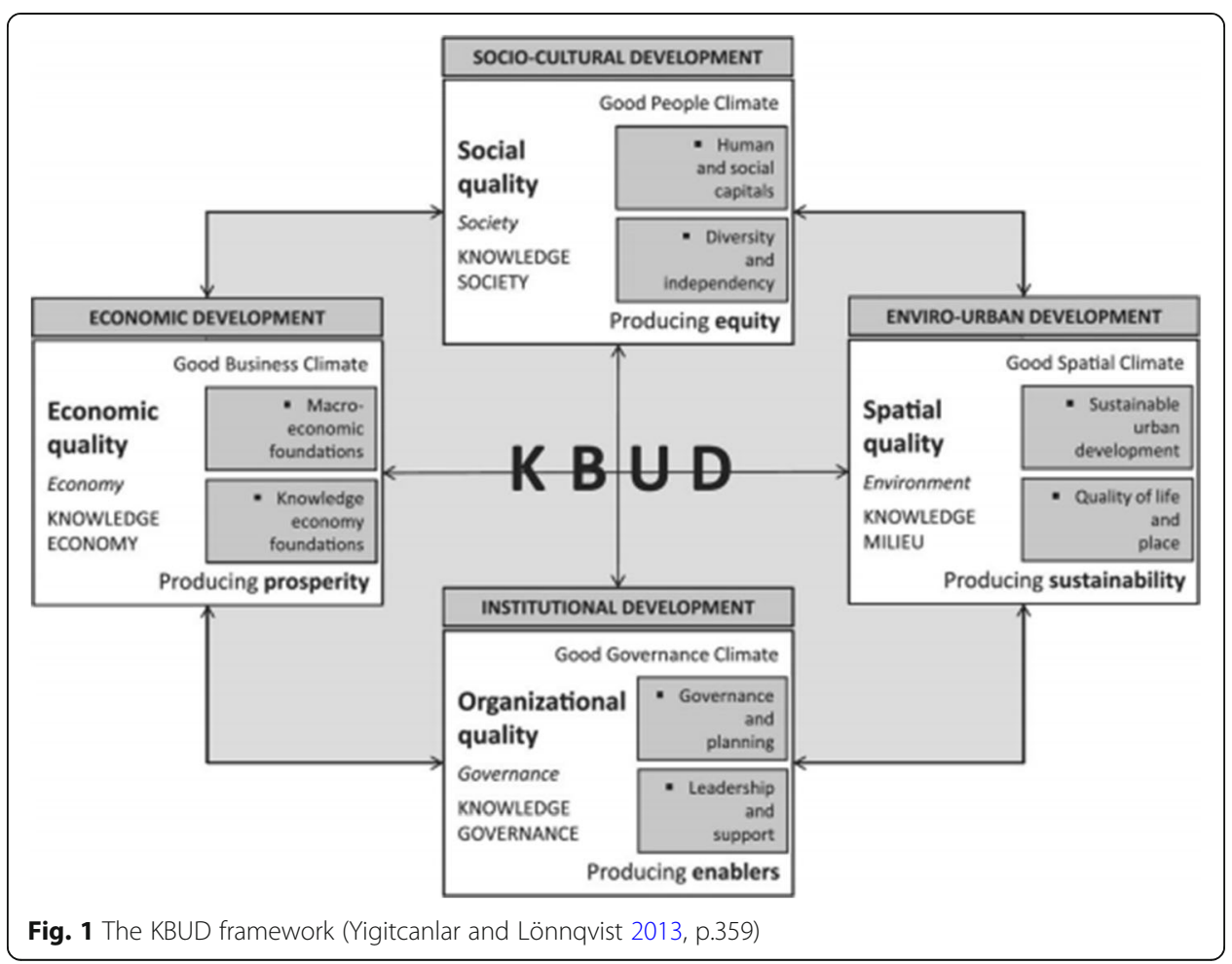

where multi-stakeholder governance is oriented to accelerate urban sustainability transitions.

According to Bulkeley et al. (2016), what differentiates urban living labs is the fact that they operate as an 'explicit form of intervention' to intentionally deliver impact in the sustainability goals of a city, by being based on 'knowledge and learning' to do so. New forms of urban governance and planning are key to promote sustainable cities (McCormick et al. 2013). Operating spaces where knowledge is shared and co-produced are important elements for building an urban environmental governance to take place. (Frantzeskaki and Kabisch 2016).

As suggested by Anttiroiko (2016), a city working as a platform would encourage citizen participation and promote relevant stakeholder engagement. Without appropriate spaces of dialogue and experimentation, local government distances itself from the citizens and turns to its own structure, failing in deliver a good governance for the city to meet its expectations. The adoption of a transdisciplinary vision in urban governance suggests that knowledge creation can emerge from all interested actors in the city, and not only from small groups in the public sector or the academy. It is something innovative and that can be more stimulated so one could expect better results in urban interventions (Maiello et al. 2011). The complexity that is present in urban daily life makes visible the difficulty of local governments to solve alone the problems that affect the city as a whole. According to Ding et al. (2015), a local government should seek to promote people-centred policies, with greater accessibility, and develop urban planning that meets the expectations of its citizens.

The innovation driver refers to the fast forward entrepreneur spirit of bringing up new solutions incessantly, the connectivity between actors of the innovation ecosystem, the ability to mobilise resources in new formats and the trial and error problem-solving 


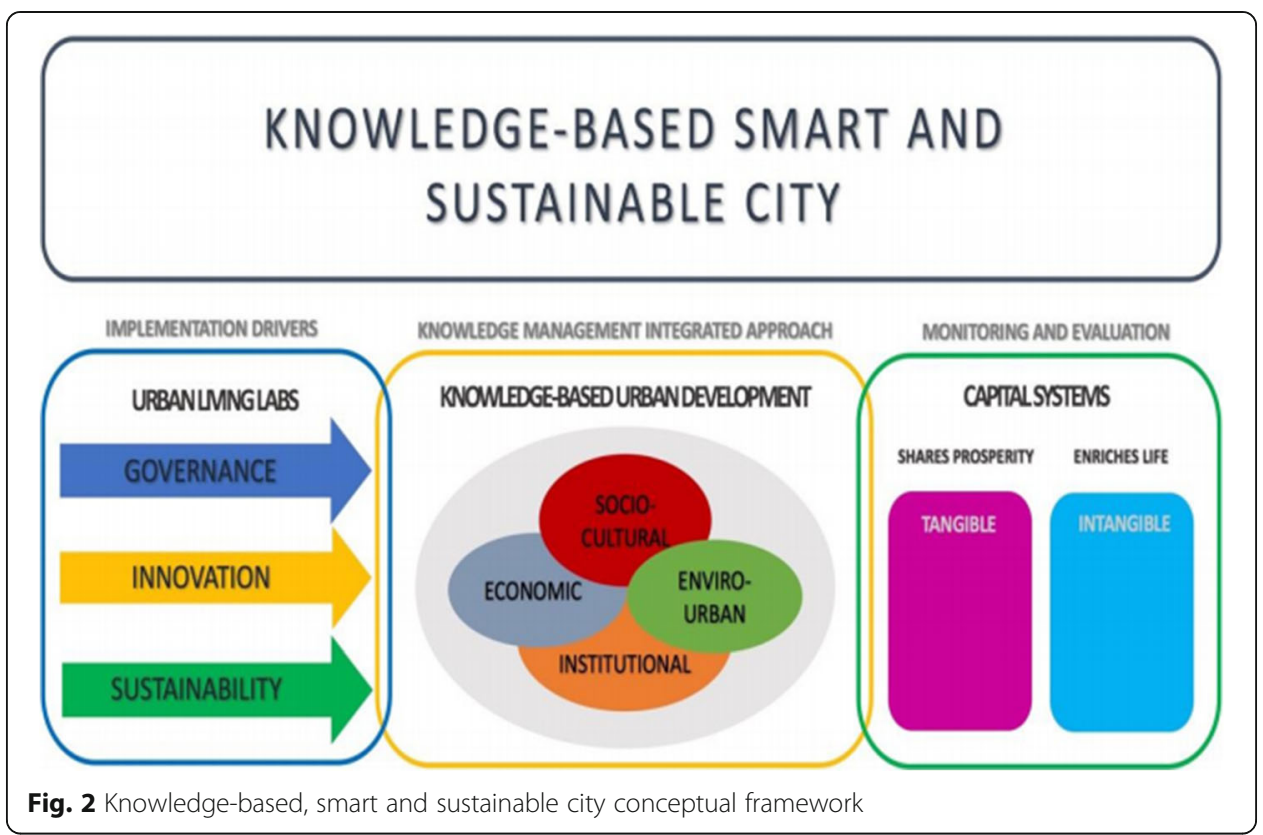

experimentation process (Messeni-Petruzzelli et al. 2010; Millar and Ju Choi 2010). Franz (2015) states that innovation development with citizen participation is aimed in a living lab initiative. Urban transitions towards sustainable cities involve "entrepreneurial capacity as well as structuring knowledge for action" (Nevens et al. 2013, p.116). An urban challenge requires knowledge networks to combine in order to produce answers and prototypes of potential solutions to cities.

Integrated and coherent solutions bring synergies and systemic gains to the city. Nature-based solutions, low carbon pathways; the enhancement of urban life must be guided by sustainability as a normative view or wishful state. The very transdisciplinary nature of sustainability suggests this approach, where theory and practice, to make and to know, coexists and feeds each other in the constant movement of the city. In this sense, Liu et al. (2014, p.31) remarks that China "is becoming a vast living laboratory of experiments in sustainable urban development". The urban transition from fossil to renewables inducts transformations in the urban arena and can be smarter if coordinated with each other and in harmony with the overall guidelines of a shared common vision, so that they can turn into a permanent practice of planning and experimentation with appropriate means.

\section{Knowledge management integrated approach}

KBUD is the heart of the urban project, playing the role of the key executive body of a sustainable city knowledge management. KBUD organises and regulates all relevant knowledge processes and functions (Metaxiotis et al. 2010). Its mechanics relies on the existence of knowledge as the central element that connects and expands itself by establishing networks and networks that intertwine themselves into knowledge grids, embracing a comprehensive holistic knowledge web.

KBUD development domains shed light into how a city knowledge management should organise itself in terms of guidelines, priorities, macro-processes, mission-oriented urban 
challenges, in order to enable a KBUD dynamics (Yigitcanlar 2014b). It is an integrated approach since it has a system thinking way of addressing effective solutions for complex urban issues that are interconnected and usually create multiple impacts.

\section{Monitoring and evaluation}

Monitoring and evaluation relates with the knowledge structures that operate as mechanisms of both regulation and control of vital activities and functions of urban systems and the evaluation framework that measure the value of the system in a comprehensive, holistic way. Capital systems is a framework common to knowledge management to build a KBD systematic approach (Carrillo 2002). Capital systems as monitoring and evaluation means that the evaluation framework will emerge in order to capture the multiple forms that knowledge is valued and then converted into tangible or intangible assets. Schiuma \& Lerro (2010, p.41) describe knowledge as "both a resource and a source of a competence and capability", tangible or intangible, driven to deliver value.

According to Carrillo (2004), the relevant aspect that alive a city resides on its value system, which makes people to recognise it and eventually organise themselves around its structure of value. Nowadays, intangible assets are being of greater concern, even national accounting systems are trying to develop new schemes to measure intangibles, such the national happiness index in Bhutan. Carrillo and Batra (2012) extensively discussed the complexity of elements regarding knowledge measurement, from intangibility to evaluation associated high costs, lack of data availability and comparability, and multidimensional evaluation procedures. In spite of the challenges to assess KBD, from a conceptual point of view, it radically differs from traditional approaches focused heavily on tangible assets that are scarcity-driven, since it is more oriented to capture the full spectrum of knowledge as value.

Capital systems has proved to be a viable tool for monitoring and evaluation a KBD process focused on the creative economy, and adherent with the intent of promoting the sustainable development of Bento Gonçalves city in Brazil (Fachinelli et al. 2014). Capital systems can be configured to operate in specific knowledge wireframes, so that is able to embrace existing datasets, indicators and other reliable data that are interoperable and assembled into and evaluation framework that can evolve over time. Fachinelli et al. (2015a) demonstrate the adherence of capital systems categories to the Human Development Index (HDI) in 150 cities in Brazil. Moreover, the study reveals the viability of Capital Systems as a flexible measuring system able to adapt to high quality and available datasets.

The recent widespread of open data, supported by ICT new technologies, internet of things (IoT), and big data, within an emerging citizen science context, could make the adoption of capital systems a promising assessment approach that can be applied to cities aiming their sustainability path through a KBD strategy (Fachinelli et al. 2015b). Thus, it would be possible by a community to setup targets and wishful benchmarks to their urban master plan so that the monitoring and evaluation component is able to be aware of the dynamic state where the system operates in its inner correction, or in other words, to monitor the city's desirable overall sustainability state. After all, to create value consistently in a sustainable city means to reach a high level of shared prosperity and to enrich life of its inhabitants. 


\section{Conclusions}

In a highly urbanising world, the task of assessing smart and sustainable cities is a hard one, evolving many different dimensions and high levels of complexity and systemic interdependence (Zhao et al. 2008). Smart and sustainable city assessment models can benefit from an integrated approach, so they can provide not only subsidies for mainstreaming evidence-based policymaking, but also to foster a cumulative process of KBUD within the city. Maiello et al. (2011) recommend investigating new visions for the smart and sustainable development of cities. The study at hand has shown us that smart and sustainable cities are a diffuse concept with many different assessment approaches. When sustainability is a major guideline in a city's long-term vision, the actions of the present time should seek to be align with a common vision of future, where the attainment of a higher quality of life today does not undermine the opportunities of the next generations to thrive.

The smart and sustainable city as the ultimate goal of its citizens helps to establish the necessary boundaries, key priorities, long-term urban planning and the inevitable integration of knowledge management processes. Breaking unsustainable patterns, in many cases, involves cultural changes in human behaviour and citizen practice that only matures in the long term and are difficult to measure. In Egger (2006, p.1246) words, "people have the ability to influence sustainability by understanding how the city system relates to humanity and the biosphere and taking the necessary action to ensure development is sensitive to others in current and future generations".

Cities are also reflecting the transition from industrial to knowledge-based, from unrealised to fully available, from linear to systemic, from national to planetary (Carrillo 2002), so the tension between the coexistence of both old and new paradigms reflects in what people attribute as value as well. One could expect major shifts in the way human life unfolds since the knowledge era is a 21st century phenomena still in its early stages, moving from tangible assets to intangible assets, with perceived knowledge being a value, as capital.

KBUD as a development strategy reveals to be a smooth fit to promote smart and sustainable cities. It can work as the vessel of the knowledge management of a city by articulating four development domains in a comprehensive way. Bulkeley et al. (2016, p.13) define urban living labs as "sites devised to design, test and learn from innovation in real time in order to respond to particular societal, economic and environmental issues in a given urban place". Urban living labs are currently playing the orchestration role in urban sustainability transitions, in many smart cities such as Amsterdam, can be a promising innovative urban planning strategy to accelerate the promotion of smart and sustainable cities.

This paper advocates the merger of KBUD, smart city and sustainable development concepts. It, furthermore, provokes the readers with a knowledge-based, smart and sustainable city conceptual framework proposal. More analytical studies and practical experimentations are necessary to bring evidence in order to check for the consistency of the proposed conceptual framework. Our prospective research will focus on to seek to combine scientific knowledge with real urban experiences, where the production of transdisciplinary knowledge could help foster urban transitions to more smart and sustainable cities. 
Funding

Not applicable

Availability of data and materials

Not applicable

\section{Authors' contributions}

This paper represents a result of collegial teamwork. The authors designed the research jointly. The first author conducted the literature review and framework development, and prepared the first draft of the manuscript. All other authors provided input that helped finalising the manuscript. All authors read and approved the final manuscript.

\section{Competing interests}

The authors declare that they have no competing interests.

\section{Publisher's Note}

Springer Nature remains neutral with regard to jurisdictional claims in published maps and institutional affiliations.

\section{Author details}

'Engineering and Knowledge Management, Federal University of Santa Catarina, Campus Universitário, Trindade, Florianópolis, SC CEP 88040-900, Brazil. World Capital Institute, 60 Ridge Street, Greenslopes, QLD 4120, Australia.

Received: 29 December 2017 Accepted: 1 February 2018

Published online: 13 February 2018

\section{References}

Ahvenniemi, H., Huovila, A., Pinto-Seppä, I., \& Airaksinen, M. (2017). What are the differences between sustainable and smart cities? Cities, 60, 234-245.

Anttiroiko, A. V. (2016). City-as-a-platform: The rise of participatory innovation platforms in Finnish cities. Sustainability, 8(9), 922.

Arslan, T. V., Durak, S., \& Aytac, D. O. (2016). Attaining SDG11: Can sustainability assessment tools be used for improved transformation of neighbourhoods in historic city centers? Natural Resources Forum, 40(4), 180-202.

Baffour, K. G., \& Booth, C. A. (2014). Integrated management framework for sustainable cities: Insights into multiple concepts and principles. WIT Transactions on Ecology and the Environment, 191, 111-123.

Baum, S., O'Connor, K., \& Yigitcanlar, T. (2009). The implications of creative industries for regional outcomes. International Journal of Foresight and Innovation Policy, 5(1-3), 44-64.

Bourdic, L., Salat, S., \& Nowacki, C. (2012). Assessing cities: A new system of cross-scale spatial indicators. Building Research and Information, 40(5), 592-605.

Bulkeley, H., Coenen, L., Frantzeskaki, N., Hartmann, C., Kronsell, A., Mai, L., \& Palgan, Y. V. (2016). Urban living labs: Governing urban sustainability transitions. Current Opinion in Environmental Sustainability, 22, 13-17.

Carrillo, F. J. (2002). Capital systems: Implications for a global knowledge agenda. Journal of Knowledge Management, 6(4), 379-399.

Carrillo, F. J. (2004). Capital cities: A taxonomy of capital accounts for knowledge cities. Journal of Knowledge Management, 8(5), 28-46.

Carrillo, F. J. (2014). What 'knowledge-based' stands for? A position paper. International Journal of Knowledge-Based Development, 5(4), 402-421.

Carrillo, F. J., \& Batra, S. (2012). Understanding and measurement: Perspectives on the evolution of knowledge-based development. International Journal of Knowledge-Based Development, 3(1), 1-16.

Carrillo, J., Yigitcanlar, T., Garcia, B., \& Lonnqvist, A. (2014). Knowledge and the city: Concepts, applications and trends of knowledge-based urban development. New York: Routledge.

Choon, S. W., Siwar, C., Pereira, J. J., Jemain, A. A., Hashim, H. S., \& Hadi, A. S. (2011). A sustainable city index for Malaysia. International Journal of Sustainable Development and World Ecology, 18(1), 28-35.

De Jong, M., Joss, S., Schraven, D., Zhan, C., \& Weijnen, M. (2015). Sustainable-smart-resilient-low carbon-eco-knowledge cities; making sense of a multitude of concepts promoting sustainable urbanization. Journal of Cleaner Production, 30, 25-38.

Ding, X., Zhong, W., Shearmur, R. G., Zhang, X., \& Huisingh, D. (2015). An inclusive model for assessing the sustainability of cities in developing countries: Trinity of cities' sustainability from spatial, logical and time dimensions (TCS-SLTD) Journal of Cleaner Production, 109, 62-75.

Dizdaroglu, D., \& Yigitcanlar, T. (2014). A parcel-scale assessment tool to measure sustainability through urban ecosystem components: The MUSIX model. Ecological Indicators, 41(1), 115-130.

Dizdaroglu, D., \& Yigitcanlar, T. (2016). Integrating urban ecosystem sustainability assessment into policy-making: Insights from the gold Coast City. Journal of Environmental Planning and Management, 59(11), 1982-2006.

Dizdaroglu, D., Yigitcanlar, T., \& Dawes, L. (2012). A micro-level indexing model for assessing urban ecosystem sustainability. Smart and Sustainable Built Environment, 1(3), 291-315.

Dur, F., \& Yigitcanlar, T. (2015). Assessing land-use and transport integration via a spatial composite indexing model. International journal of Environmental Science and Technology, 12(3), 803-816.

Dur, F., Yigitcanlar, T., \& Bunker, J. (2014). A spatial indexing model for measuring neighbourhood level land-use and transport integration. Environment and Planning B, 41(5), 792-812.

Egger, S. (2006). Determining a sustainable city model. Environmental Modelling and Software, 21(9), 1235-1246.

Egilmez, G., Gumus, S., \& Kucukvar, M. (2015). Environmental sustainability benchmarking of the U.S. and Canada metropoles: An expert judgment-based multi-criteria decision-making approach. Cities, 42, 31-41.

Ergazakis, K., \& Metaxiotis, K. (2011). The knowledge-based development agenda: A perspective for 2010-2020. VINE: The Journal of Information and Knowledge Management, 41(3), 358-377. 
Fachinelli, A. C., Carrillo, F. J., \& D’Arisbo, A. (2014). Capital system, creative economy and knowledge city transformation: Insights from Bento Gonçalves, Brazil. Expert Systems with Applications, 41(12), 5614-5624.

Fachinelli, A. C., D’Arrigo, F. P., \& Giacomello, C. P. (2015a). Open data for sustainability performance assessment in Brazilian cities. Australian Journal of Basic and Applied Sciences, 9(20), 32-38.

Fachinelli, A. C., Giacomello, C. P., \& Larentis, F. (2015b). The influence of capital system categories on human development index in Brazil. International Journal of Knowledge-Based Development, 6(4), 350-369.

Ferenhof, H., \& Fernandes, R. (2016). Desmistificando a revisão de literatura como base para a redação científica: método SSF. Revista ACB, 21, 550-563.

Frantzeskaki, N., \& Kabisch, N. (2016). Designing a knowledge co-production operating space for urban environmental governance: Lessons from Rotterdam, Netherlands and Berlin, Germany. Environmental Science \& Policy, 62, 90-98.

Franz, Y. (2015). Designing social living labs in urban research. Info, 17(4), 53-66.

Goonetilleke, A., Yigitcanlar, T., Ayoko, G., \& Egodawatta, P. (2014). Sustainable urban water environment: Climate, pollution and adaptation. Cheltenham: Edward Elgar Publishing.

Kamruzzaman, M., Hine, J., \& Yigitcanlar, T. (2015). Investigating the link between carbon dioxide emissions and transport related social exclusion in rural Northern Ireland. International journal of Environmental Science and Technology, 12(11), 3463-3478.

Kennedy, C. A. (2002). A comparison of the sustainability of public and private transportation systems: Study of the greater Toronto area. Transportation, 29(4), 459-493.

Knight, R. V. (1995). Knowledge-based development: Policy and planning implications for cities. Urban Studies, 32(2), $225-260$.

Lara, A., Costa, E., Furlani, T., \& Yigitcanlar, T. (2016). Smartness that matters: Comprehensive and human-centred characterisation of smart cities. Journal of Open Innovation: Technology, Market, and Complexity, 2, 8.

Liu, H., Zhou, G., Wennersten, R., \& Frostell, B. (2014). Analysis of sustainable urban development approaches in China. Habitat International, 41, 24-32.

Lönnqvist, A., Käpylä, J., Salonius, H., \& Yigitcanlar, T. (2014). Knowledge that matters: Identifying regional knowledge assets of the Tampere region. European Planning Studies, 22(10), 2011-2029.

Maiello, A., Battaglia, M., Daddi, T., \& Frey, M. (2011). Urban sustainability and knowledge: Theoretical heterogeneity and the need of a transdisciplinary framework: A tale of four towns. Futures, 43(10), 1164-1174.

McCormick, K., Anderberg, S., Coenen, L., \& Neij, L. (2013). Advancing sustainable urban transformation. Journal of Cleaner Production, 50, 1-11.

Messeni-Petruzzelli, A., Albino, V., Carbonara, N., \& Rotolo, D. (2010). Leveraging learning behavior and network structure to improve knowledge gatekeepers' performance. Journal of Knowledge Management, 14(5), 635-658.

Metaxiotis, K., Carrillo, F. J., \& Yigitcanlar, T. (Eds.). (2010). Knowledge-based development for cities and societies: Integrated multi-level approaches. Hersey: IGI Global.

Millar, C. C., \& Ju Choi, C. (2010). Development and knowledge resources: A conceptual analysis. Journal of Knowledge Management, 14(5), 759-776.

Monfaredzadeh, T., \& Berardi, U. (2015). Beneath the smart city: Dichotomy between sustainability and competitiveness. International Journal of Sustainable Building Technology and Urban Development, 6(3), 140-156.

Mori, K., \& Yamashita, T. (2015). Methodological framework of sustainability assessment in city sustainability index (CSI): A concept of constraint and maximisation indicators. Habitat International, 45, 10-14.

Nevens, F., Frantzeskaki, N., Gorissen, L., \& Loorbach, D. (2013). Urban transition labs: Co-creating transformative action for sustainable cities. Journal of Cleaner Production, 50, 111-122.

Newman, P. W. (1999). Sustainability and cities: Extending the metabolism model. Landscape and Urban Planning, 44(4), $219-226$.

Pancholi, S., Yigitcanlar, T., \& Guaralda, M. (2015). Public space design of knowledge and innovation spaces: Learnings from Kelvin Grove Urban Village, Brisbane. Journal of Open Innovation: Technology, Market, and Complexity, 1, 13.

Phillis, Y. A., Kouikoglou, V. S., \& Verdugo, C. (2017). Urban sustainability assessment and ranking of cities. Computers, Environment and Urban Systems, 64, 254-265.

Prata, J., Arsenio, E., \& Pontes, J. P. (2014). Moving towards the sustainable city: The role of electric vehicles, renewable energy and energy efficiency. WIT Transactions on Ecology and the Environment, 179, 871-883.

Sarimin, M., \& Yigitcanlar, T. (2012). Towards a comprehensive and integrated knowledge- based urban development model: Status quo and directions. International Journal of Knowledge-Based Development, 3(2), 175-192.

Schiuma, G., \& Lerro, A. (2010). Knowledge-based dynamics of regional development: The intellectual capital innovation capacity model. International Journal of Knowledge-Based Development, 1(1-2), 39-52.

Sherry, L. (2002). Sustainability of innovations. Journal of Interactive Learning Research, 13(3), 211.

Trindade, E., Hinnig, M., Costa, E., Sabatini-Marques, J., Bastos, R., \& Yigitcanlar, T. (2017). Sustainable development of smart cities: A systematic review of the literature. Journal of Open Innovation: Technology, Market, and Complexity, 3, 11.

Tumini, I. (2016). A theoretical approach for integrating resiliency concepts to urban sustainability indicators. Revista de Urbanismo, 34, 4-19.

Voytenko, Y., McCormick, K., Evans, J., \& Schliwa, G. (2016). Urban living labs for sustainability and low carbon cities in Europe: Towards a research agenda. Journal of Cleaner Production, 123, 45-54.

Yang, D., Kao, W. T. M., Zhang, G., \& Zhang, N. (2014). Evaluating spatiotemporal differences and sustainability of Xiamen urban metabolism using energy synthesis. Ecological Modelling, 272, 40-48.

Yigitcanlar, T. (2009). Planning for smart urban ecosystems: Information technology applications for capacity building in environmental decision making. Theoretical and Empirical Researches in Urban Management, 4(3), 5-21.

Yigitcanlar, T. (2010). Making space and place for the knowledge economy: Knowledge-based development of Australian cities. European Planning Studies, 18(11), 1769-1178.

Yigitcanlar, T. (2011). Position paper: Redefining knowledge-based urban development. International Journal of Knowledge-Based Development, 2(4), 340-356.

Yigitcanlar, T. (2014a). Position paper: Benchmarking the performance of global and emerging knowledge cities. Expert Systems with Applications, 41(12), 5549-5559.

Yigitcanlar, T. (2014b). Innovating urban policymaking and planning mechanisms to deliver knowledge-based agendas: A methodological approach. International Journal of Knowledge-Based Development, 5(3), 253-270.

Yigitcanlar, T. (2015). Smart cities: An effective urban development and management model? Australian Planner, 52(1), 27-34. 
Yigitcanlar, T. (2016). Technology and the city: Systems, applications and implications. New York: Routledge.

Yigitcanlar, T., \& Bulu, M. (2015). Dubaization of Istanbul: Insights from the knowledge-based urban development journey of an emerging local economy. Environment and Planning A, 47(1), 89-107.

Yigitcanlar, T., \& Dizdaroglu, D. (2015). Ecological approaches in planning for sustainable cities: A review of the literature. Global Journal of Environmental Science and Management, 1(2), 71-94.

Yigitcanlar, T., \& Dur, F. (2010). Developing a sustainability assessment model: The sustainable infrastructure, land-use, environment and transport model. Sustainability, 2(1), 321-340.

Yigitcanlar, T., Dur, F., \& Dizdaroglu, D. (2015c). Towards prosperous sustainable cities: A multiscalar urban sustainability assessment approach. Habitat International, 45, 36-46.

Yigitcanlar, T., Edvardsson, I., Johannesson, H., Kamruzzaman, M., loppolo, G., \& Pancholi, S. (2017). Knowledge-based development dynamics in less favoured regions: Insights from Australian and Icelandic university towns. European Planning Studies, 25(12), 2272-2292.

Yigitcanlar, T., Inkinen, T., \& Makkonen, T. (2015b). Does size matter? Knowledge-based development of second-order city-regions in Finland. disP-The Planning Review, 51(3), 62-77.

Yigitcanlar, T., \& Kamruzzaman, M. (2015). Planning, development and management of sustainable cities: A commentary from the guest editors. Sustainability, 7(11), 14677-14688.

Yigitcanlar, T., Kamruzzaman, M., \& Teriman, S. (2015a). Neighborhood sustainability assessment: Evaluating residential development sustainability in a developing country context. Sustainability, 7(3), 2570-2602.

Yigitcanlar, T., \& Kamruzzaman, M. (2018). Does smart city policy lead to sustainability of cities? Land Use Policy, https://doi.org/10.1016/j.landusepol.2018.01.034.

Yigitcanlar, T., \& Lee, S. (2014). Korean ubiquitous-eco-city: A smart-sustainable urban form or a branding hoax? Technological Forecasting and Social Change, 89(1), 100-114.

Yigitcanlar, T., \& Lönnqvist, A. (2013). Benchmarking knowledge-based urban development performance: Results from the international comparison of Helsinki. Cities, 31, 357-369.

Yigitcanlar, T., Metaxiotis, K., \& Carrillo, F. J. (Eds.). (2012). Building prosperous knowledge cities: Policies, plans and metrics. Cheltenham: Edward Elgar Publishing.

Yigitcanlar, T., \& Sarimin, M. (2015). Multimedia super corridor, Malaysia: Knowledge-based urban development lessons from an emerging economy. VINE: The Journal of Information and Knowledge Management, 45(1), 126-147.

Zhao, J., Zhu, Y. G., Shao, G., \& Ness, D. (2008). Coping with an urbanising world: Interdisciplinary research towards sustainability. The International Journal of Sustainable Development \& World Ecology, 15(4), 284-287.

\section{Submit your manuscript to a SpringerOpen ${ }^{\circ}$ journal and benefit from:}

- Convenient online submission

- Rigorous peer review

- Open access: articles freely available online

- High visibility within the field

- Retaining the copyright to your article

Submit your next manuscript at $\gg$ springeropen.com 